\title{
Accumulation of $\mathrm{Cd}, \mathrm{Cu}, \mathrm{Pb}$, and $\mathrm{Zn}$ in water, sediments, and mangrove crabs (Sesarma mederi) in the upper Gulf of Thailand
}

\author{
Rattanawat Chaiyara $^{\mathrm{a}, *}$, Montri Ngoendee ${ }^{\mathrm{b}}$, Maleeya Kruatrachue ${ }^{\mathrm{c}}$ \\ a Wildlife and Plant Research Centre, Faculty of Environment and Resource Studies, Mahidol University, \\ 999 Phuthamonthon 4, Salaya, Phuthamonthon, Nakhon Pathom 73170 Thailand \\ b Bang Poo Nature Study Centre, World Wildlife Fund-Thailand, Sukhumvit Road, Samut Prakarn, Thailand \\ c Department of Biology, Faculty of Science and International College Mahidol University, Rama 6, \\ Bangkok 10400 Thailand
}

*Corresponding author, e-mail: rattanawat.cha@mahidol.ac.th

Received 15 Oct 2012

Accepted 10 Apr 2013

\begin{abstract}
Mangrove crabs (Sesarma mederi) can be used as bioindicators of the environment. This study aimed to estimate the heavy metal content in $S$. mederi in various Thai mangroves and compare them with other studies for international regulations for human consumption. S. mederi were obtained from the mangroves of the Chao Phraya, Tha $\mathrm{Chin}$, and Mae Klong rivers. The concentrations of $\mathrm{Cd}, \mathrm{Cu}$, and $\mathrm{Pb}$ in the rivers were low compared to the marine standards of Thailand and estuarine water elsewhere. The concentrations of $\mathrm{Cd}$ and $\mathrm{Cu}$ in sediments were rather similar to those in other rivers. The results showed that crabs accumulated metals in the order: $\mathrm{Cd}>\mathrm{Cu}>\mathrm{Pb}>\mathrm{Zn}$. The bioconcentration factor of $\mathrm{Cd}$ and $\mathrm{Cu}$ was highest in Mae Klong, while $\mathrm{Pb}$ and $\mathrm{Zn}$ were highest in Chao Phraya. Although metal concentrations in crabs were within the ranges found in other studies, they exceeded the maximum ranges according to standards. Hence as mangrove crabs are highly consumed as traditional and international Thai food, they may be a potential health hazard for human consumers. Consequently, the use of mangrove crab could be an interesting tool for monitoring estuary pollution.
\end{abstract}

KEYWORDS: bioaccumulation, metals, mangrove ecosystems

\section{INTRODUCTION}

Metals are taken up and subsequently accumulated by organisms from natural and contaminated effluents and enter the estuarine ecosystem through direct discharges from coastal communities, ships, rivers and atmospheric deposition, and through land runoff ${ }^{1}$. A large number of metal pollutants derive from industrial and domestic wastes generated especially by the big cities ${ }^{2-4}$.

The pollution levels of the aquatic environment by metals can be estimated by analysing water, sediments, and aquatic organisms. A chemical analysis of the water does not provide complete information on the bioavailability of metals present in the environment ${ }^{5,6}$. Hence recent research related to metal pollution in aquatic systems has focused on the use of biological indicators or bioindicators. Bioindicators, also called biomonitors, are species sensitive to environmental change, habitat quality or anthropogenic influence, and thus their status can be used to infer the health of the environment or the status of other species living on similar habitat ${ }^{7}$. Aquatic species have large body to accumulate pollutants, and providing appropriate material to use them as bioindicator for an indirect estimation of the concentration of pollution in their living environment ${ }^{8-10}$. One of the crustaceans that absorb better metals and they are easy to spot and collect in large quantities, which makes easier their study compared to other organisms. Aquatic organisms have been used widely as monitors of metal concentration ${ }^{11-13}$. Aquatic organisms are often exposed to a mixture of metals rather than a single element. Metals, such as $\mathrm{Cu}$ and $\mathrm{Zn}$, play an important role in cellular metabolism and their body concentrations can be regulated by the organisms. Others, such as $\mathrm{Cd}$ and $\mathrm{Pb}$, are toxic even at low concentrations and tend to accumulate in the body of crustaceans ${ }^{11,14}$. At present, considerable evidence exists to show that certain metals are a threat to human health when consumed even at trace levels ${ }^{15}$.

Levels and accumulations of metals in marine organisms usually fluctuate as the change of some seasonal factors such as seasonal dietary, temperature, 
and salinity ${ }^{16}$. The salinity of water appears to influence the uptake of metals as higher levels of metals are found during the flooding season when salinity is lower ${ }^{17}$. The accumulations of $\mathrm{Cd}, \mathrm{Cu}, \mathrm{Pb}$, and $\mathrm{Zn}$ are likely to vary within organisms ${ }^{18}$.

In Thailand, metals contaminate estuarine areas such as the ones of Chao Phraya River (CP), Tha Chin River (TH), and Mae Klong River (MK) ${ }^{19-21}$. The $\mathrm{CP}, \mathrm{TC}$, and MK flow through the densely populated central plain of Thailand before discharging into the upper Gulf of Thailand. Because of its nutrient-rich, shallow waters, and confined nature, these ecosystems are especially vulnerable to human activities. The principal cause of the declining of fishery production in the Gulf of Thailand is overfishing. However, Detrimental effects of pollution on these ecosystems are believed to have an increased significant amount of metals ${ }^{22}$. The rapidly increasing population with associated industrialization and economic development in the coastal areas, combined with insufficient environmental protection measures, may have led to elevated levels of metal pollution in Thailand ${ }^{23}$. A study on metal pollution in the upper Gulf of Thailand indicated that the accumulations of $\mathrm{Pb}, \mathrm{Zn}, \mathrm{Cu}$, and $\mathrm{Cd}$ in the waters of river mouth vicinities were significant, which may have a long term impact on the aquatic environment through precipitation of metals to the bottom sediments and bioaccumulation and biomagnification of metals in various food chains ${ }^{24}$.

In this study, the accumulations of $\mathrm{Cd}, \mathrm{Cu}, \mathrm{Pb}$, and $\mathrm{Zn}$ in mangrove crabs (Sesarma mederi), from $\mathrm{CP}$, MK, and TC were studied. S. mederi is a detritivore decomposing plant and animal parts as well as organic faecal matter. Crabs are common in the diet of local inhabitants and its fishery has a considerable economic importance ${ }^{25}$. The concentrations of metals in $S$. mederi may diagnose the degree of contamination of metals in the coastal zone when compared the concentrations of metals between the river mounts along a coastal area. Moreover, the results may be compared with those of similar studies and with the existing international regulations related to the content of metals in crustaceans for human consumption.

\section{MATERIALS AND METHODS}

The Gulf of Thailand extends from the shallow western part of the South China Sea over $750 \mathrm{~km}$ to the north between the Thai-Malaysian peninsula and Indo-China. The northern boundary is the coast of the central plain of Thailand. The total area of the gulf is about $32000 \mathrm{~km}^{2}$ with an average depth of $45 \mathrm{~m}$. Maximum depth in the central part ranges from 70 $85 \mathrm{~m}$. The square $\left(100 \times 100 \mathrm{~km}^{2}\right)$ upper part of the

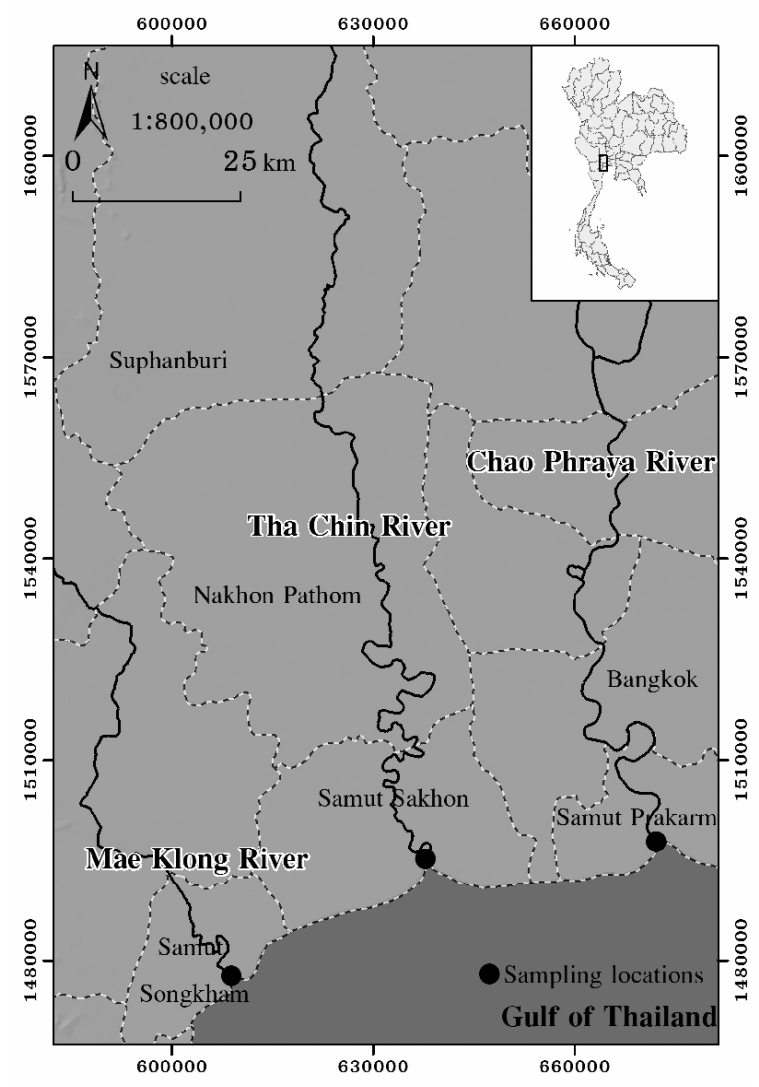

Fig. 1 The Chao Phraya Delta comprises 3 major river basins, the Chao Phraya (CP), Tha Chin (TC), and Mae Klong (MK).

gulf has an average depth of $15 \mathrm{~m}$. The water depth increases gradually from the shallow northern coast, Bangkok bar, to a mean depth of $25 \mathrm{~m}$ at its mouth between Hua Hin and Sattahip. The eastern part, with its rock offshore islands, is slightly deeper than the western part. There are 5 rivers entering the northern coast of the upper gulf from west to east: Phetchaburi province, $\mathrm{MK}, \mathrm{TC}, \mathrm{CP}$ and Bang Pakong. In the past, these rivers are the major sources of pollutants in this upper part of the gulf, especially $\mathrm{MK}, \mathrm{TC}$, and $\mathrm{CP}^{26}$.

\section{Collection and preparation of samples}

Mangrove crabs were trapped by indigenous crab live traps in the estuary under the mangrove forests of $\mathrm{CP}$, TC, and MK (50 m from the Gulf of Thailand; UTM Zone 47, $679302 \mathrm{~m} \mathrm{~N} 1494887 \mathrm{~m} \mathrm{E}, 637750 \mathrm{~m}$ N 1493028 m E, and 608357 m N 1476672 m E, Fig. 1). From higher to lower human activity: CP is mainly rice fields, has the highest number of industrial estates, and metropolitan areas, TC has mainly marine frozen food industries, and $\mathrm{MK}$ is an agricultural area 
with agriculture industries. Each river had 3 trapping sites (20 traps per site, $10 \mathrm{~m}$ distance from each other), $10 \mathrm{~S}$. mederi were trapped randomly in each trapping site in each month in the dry (December 2006, February and April 2007) and wet seasons (January, August, and October 2007). All crabs were washed in running tap water for $5 \mathrm{~min}$. Samples were rinsed twice with deionized water and their fresh weights were recorded. Then, they were separated into tissues and carapaces and dried at $60^{\circ} \mathrm{C}$ for 2 days in a hot air oven to a constant weight. Dry weights of tissues and carapaces were determined. Corresponding 6 sediments $(1 \mathrm{~m}$ depth) and 6 estuarine water samples (30 $\mathrm{cm}$ depth) were collected randomly at each trapping area in each month.

\section{RESULTS}

\section{Metals in water and sediment}

Dry tissues and carapace samples were ground with a mortar and pestle. $0.5 \mathrm{~g}$ dry weight of crab samples was digested with $5 \mathrm{ml}$ nitric acid $\left(69 \% \mathrm{HNO}_{3}, \mathrm{BDH}\right)$ and impurities were removed by filtration ${ }^{27}$. Soil samples were ground and passed through a $2 \mathrm{~mm}$ nylon sieve. $0.5 \mathrm{~g}$ of soil sample was digested with $5 \mathrm{ml}$ nitric acid $\left(69 \% \mathrm{HNO}_{3}, \mathrm{BDH}\right)$ and impurities removed by filtration ${ }^{27}$. Water samples were aciddigested with $10 \mathrm{ml}$ of $65 \% \mathrm{HNO}_{3}$ (analytical-reagent grade) and evaporated until the total volume reached to approximately $1 \mathrm{ml}$. Then the mixture was digested using $5 \mathrm{ml}$ of diluted $\mathrm{HNO}_{3}(1: 49, V / V)$ for $12 \mathrm{~h}$ at room temperature ${ }^{12}$. The absorption wavelength and detection limit were $228.8 \mathrm{~nm}$ and $0.02 \mu \mathrm{g} / \mathrm{g}$ for $\mathrm{Cd}$, $283.3 \mathrm{~nm}$ and $0.05 \mu \mathrm{g} / \mathrm{g}$ for $\mathrm{Pb}, 324.8 \mathrm{~nm}$ and $0.2 \mu \mathrm{g} / \mathrm{g}$ for $\mathrm{Cu}, 248.3 \mathrm{~nm}$ and $0.05 \mu \mathrm{g} / \mathrm{g}$ for $\mathrm{Zn}$. The recovery tests for standards (analytical grade, E. Merck) were 99.8\% for $\mathrm{Cd}, 99.4 \%$ for $\mathrm{Pb}, 98 \%$ for $\mathrm{Cu}$ and $99.4 \%$ for $\mathrm{Zn}$. After digestion, $\mathrm{Cd}, \mathrm{Cu}, \mathrm{Pb}$, and $\mathrm{Zn}$ concentrations in tissue, carapace, sediment, and water samples were measured by a flame atomic absorption spectrophotometer (FAAS; Variance SpectrAA 55B). To assess the analytical precision, three replicates of analytical samples, an appropriate standard reference material and a regent blank were performed in each analytical batch. FAAS was also verified by the laboratory of the Department of Primary Industries and Mines, the laboratory of the Department of Soil Science, Ministry of Agriculture and Cooperatives, and the Central Instrument Facilities, Faculty of Science, Mahidol University.

The dry weight of the biota-sediment accumulation factor (BSAF, i.e., the concentration of a particular metal in tissue per concentration of such metal in sediment, also called enrichment ratio) of tissues in comparison with element concentrations in the sediments was assumed to equal to $20 \%$ of wet weight, a conversion derived from the data of Williams and Robins ${ }^{12}$. BSAF was calculated as: (element concentration in tissue or carapace)/(element concentration in sediment). Data were expressed as means with standard deviation. One way ANOVA (SPSS 17.00 computer software) was used to test the effect of metals on growth and metal contents in crabs and soils. If the $F$-value showed significant differences $(p<0.05)$, means were compared with least significant difference method (LSD).

The mean water concentrations of $\mathrm{Cd}, \mathrm{Cu}, \mathrm{Pb}$, and $\mathrm{Zn}$ in waters of $\mathrm{CP}, \mathrm{TC}$, and $\mathrm{MK}$ were low when compared to the water quality parameters at the river mouths of the inner Gulf of Thailand in 1983 $(\text { Table } 1)^{28}$. All metal pollutants obtained the highest values during the dry season (Table 1). The average water $\mathrm{pH}$ values of $\mathrm{CP}, \mathrm{TC}$, and $\mathrm{MK}$ were not acidic. $\mathrm{TC}$ had the highest concentrations of $\mathrm{Cd}, \mathrm{Pb}$, and $\mathrm{Zn}$ $(p<0.05)$ with the highest values in water $\mathrm{pH}$ and salinity.

The mean concentrations in water of $\mathrm{Cd}, \mathrm{Cu}, \mathrm{Pb}$, and $\mathrm{Zn}$ were higher in the dry season for all study areas with the exception of MK. While $\mathrm{Cd}$ was different in $\mathrm{CP}$ and TC $(p<0.05), \mathrm{Cu}$ was different in $\mathrm{CP}(p<0.05)$, and $\mathrm{Pb}$ and $\mathrm{Zn}$ were different in TC $(p<0.05)$ between dry and wet seasons due to the effect of rain and flooding during the wet season (Table 1).

The mean concentrations of $\mathrm{Cd}$ and $\mathrm{Cu}$ in sediments of $\mathrm{CP}, \mathrm{TC}$, and $\mathrm{MK}$ were similar to those concentrations in water, while $\mathrm{Pb}$ and $\mathrm{Zn}$ concentrations were higher than those of the water (Table 1). Cd was highest in $\mathrm{TC}$ in wet season, $\mathrm{Cu}$ was highest in $\mathrm{CP}$ in dry season, $\mathrm{Pb}$ was highest in $\mathrm{MK}$ in wet season and $\mathrm{Zn}$ was highest in MK in dry season. The mean sediment concentrations of $\mathrm{Cd}, \mathrm{Cu}, \mathrm{Pb}$, and $\mathrm{Zn}$ were not different between dry and wet seasons, except for $\mathrm{Cu}$ in $\mathrm{CP}$, which was higher in the dry season $(p>0.05)$. Cu source can be derived from cities and industrial activities in $\mathrm{CP}$ and reduced by flood during the wet season.

\section{Metals in mangrove crabs}

The highest concentrations of $\mathrm{Cd}, \mathrm{Cu}$, and $\mathrm{Pb}$ were in TC, while $\mathrm{Zn}$ was highest in $\mathrm{CP}$. Cd and $\mathrm{Zn}$ were mostly concentrated in the body, while $\mathrm{Cu}$ was highest in tissue, and $\mathrm{Pb}$ was highest in carapace (Table 2). $\mathrm{Cd}, \mathrm{Cu}$, and $\mathrm{Pb}$ concentrations were highest in the wet season (when there was low salinity). 
Table 1 Metal concentrations in water and sediment in dry and wet seasons in Chao Phraya (CP), Tha Chin (TC), and Mae Klong (MK) basins.

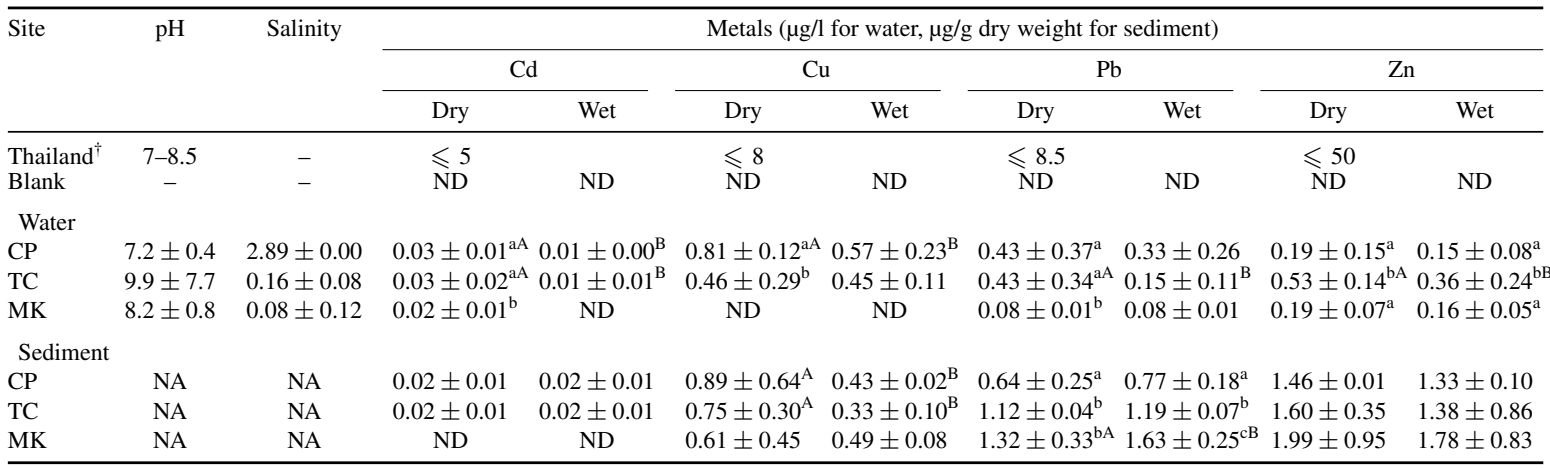

Data with different letter $(a, b, c)$ in the same column and same item, or $(\mathrm{A}, \mathrm{B})$ in the same row and same metal indicate a significant difference at $5 \%$ level by LSD test.

Thailand water standards ${ }^{29}$.

$\mathrm{ND}=$ non-detectable; $\mathrm{NA}=$ not analysed.

Table 2 Metal concentrations in tissues, carapacesm and whole body of S. mederi in the dry and wet seasons of 2007 in Chao Phraya (CP), Tha Chin (TC), and Mae Klong (MK) basins.

\begin{tabular}{|c|c|c|c|c|c|c|c|c|}
\hline \multirow[t]{3}{*}{ Crab part } & \multicolumn{8}{|c|}{ Metals ( $\mu \mathrm{g} / \mathrm{g}$ dry weight) } \\
\hline & \multicolumn{2}{|c|}{$\mathrm{Cd}$} & \multicolumn{2}{|c|}{$\mathrm{Cu}$} & \multicolumn{2}{|c|}{$\mathrm{Pb}$} & \multicolumn{2}{|c|}{$\mathrm{Zn}$} \\
\hline & Dry & Wet & Dry & Wet & Dry & Wet & Dry & Wet \\
\hline Blank & ND & ND & ND & ND & ND & ND & ND & ND \\
\hline $\begin{array}{l}\text { Whole } \\
\text { CP } \\
\text { TC } \\
\text { MK }\end{array}$ & $\begin{array}{l}3.08 \pm 0.47^{\mathrm{a}} \\
3.95 \pm 0.66^{\mathrm{b}} \\
3.92 \pm 0.78^{\mathrm{b}}\end{array}$ & $\begin{array}{l}3.74 \pm 0.50^{\mathrm{a}} \\
4.49 \pm 1.21^{\mathrm{b}} \\
3.56 \pm 1.04^{\mathrm{a}}\end{array}$ & $\begin{array}{l}1.48 \pm 0.85 \\
1.74 \pm 0.75 \\
1.30 \pm 0.79\end{array}$ & $\begin{array}{l}1.86 \pm 0.96 \\
2.10 \pm 0.83 \\
1.71 \pm 0.87\end{array}$ & $\begin{array}{l}6.10 \pm 3.11^{\mathrm{ab}} \\
7.88 \pm 5.35^{\mathrm{a}} \\
3.27 \pm 1.44^{\mathrm{b}}\end{array}$ & $\begin{array}{l}5.41 \pm 2.43^{\mathrm{ab}} \\
7.23 \pm 6.26^{\mathrm{a}} \\
2.51 \pm 2.20^{\mathrm{b}}\end{array}$ & $\begin{array}{l}4.93 \pm 0.71^{\mathrm{aA}} \\
4.58 \pm 0.36^{\mathrm{aA}} \\
4.00 \pm 0.51^{\mathrm{bA}}\end{array}$ & $\begin{array}{l}3.83 \pm 0.43^{\mathrm{aB}} \\
3.63 \pm 1.14^{\mathrm{aB}} \\
0.65 \pm 0.20^{\mathrm{bB}}\end{array}$ \\
\hline $\begin{array}{l}\text { Tissue } \\
\text { CP } \\
\text { TC } \\
\text { MK }\end{array}$ & $\begin{array}{l}1.46 \pm 0.34 \\
1.58 \pm 0.42 \\
1.35 \pm 0.49\end{array}$ & $\begin{array}{l}1.48 \pm 0.30 \\
1.54 \pm 0.19 \\
1.35 \pm 0.33\end{array}$ & $\begin{array}{l}1.74 \pm 0.35^{\mathrm{A}} \\
1.97 \pm 0.29^{\mathrm{A}} \\
1.91 \pm 0.32\end{array}$ & $\begin{array}{l}2.26 \pm 0.25^{\mathrm{B}} \\
2.26 \pm 0.14^{\mathrm{B}} \\
2.09 \pm 0.25\end{array}$ & $\begin{array}{l}2.04 \pm 1.01^{\mathrm{a}} \\
0.94 \pm 0.89^{\mathrm{b}} \\
0.54 \pm 0.25^{\mathrm{b}}\end{array}$ & $\begin{array}{l}1.92 \pm 1.05^{\mathrm{a}} \\
0.73 \pm 0.27^{\mathrm{b}} \\
0.35 \pm 0.09^{\mathrm{b}}\end{array}$ & $\begin{array}{l}4.57 \pm 0.60^{\mathrm{aA}} \\
4.35 \pm 0.22^{\mathrm{abA}} \\
3.72 \pm 0.46^{\mathrm{b}}\end{array}$ & $\begin{array}{l}3.92 \pm 0.45^{\mathrm{B}} \\
3.60 \pm 0.34^{\mathrm{B}} \\
3.80 \pm 0.50\end{array}$ \\
\hline $\begin{array}{l}\text { Carapace } \\
\text { CP } \\
\text { TC } \\
\text { MK }\end{array}$ & $\begin{array}{l}2.43 \pm 0.30^{\mathrm{a}} \\
2.92 \pm 0.55^{\mathrm{a}} \\
1.35 \pm 0.46^{\mathrm{b}}\end{array}$ & $\begin{array}{l}2.38 \pm 0.32^{\mathrm{a}} \\
3.01 \pm 0.99^{\mathrm{b}} \\
1.08 \pm 0.46^{\mathrm{c}}\end{array}$ & $\begin{array}{l}0.41 \pm 0.08 \\
0.45 \pm 0.17 \\
0.40 \pm 0.14\end{array}$ & $\begin{array}{l}0.52 \pm 0.14 \\
0.53 \pm 0.17 \\
0.50 \pm 0.19\end{array}$ & $\begin{array}{l}6.99 \pm 3.12^{\mathrm{a}} \\
7.21 \pm 5.44^{\mathrm{a}} \\
2.84 \pm 1.50^{\mathrm{b}}\end{array}$ & $\begin{array}{l}6.29 \pm 3.07^{\mathrm{a}} \\
9.33 \pm 7.76^{\mathrm{a}} \\
2.18 \pm 2.18^{\mathrm{b}}\end{array}$ & $\begin{array}{l}0.51 \pm 0.05^{\mathrm{aA}} \\
0.39 \pm 0.13^{\mathrm{b}} \\
0.37 \pm 0.09^{\mathrm{b}}\end{array}$ & $\begin{array}{l}0.40 \pm 0.12^{\mathrm{B}} \\
0.39 \pm 0.09 \\
0.38 \pm 0.11\end{array}$ \\
\hline
\end{tabular}

Data with different letter $(\mathrm{a}, \mathrm{b}, \mathrm{c})$ in the same column and same item, or (A, B) in the same row and same metal indicate a significant difference at $5 \%$ level by LSD test.

$\mathrm{ND}=$ non-detectable.

\section{Biota-sediment accumulation of metals}

To evaluate the efficiency of BSAF in $S$. mederi was determined (Fig. 2). The metals that crabs accumulated in greatest amounts in its body were $\mathrm{Cd}$, with the highest factor of BSAF of 353 in MK, 225 in CP, and 211 in TC, respectively.

\section{DISCUSSION}

The mean water concentrations in waters of $\mathrm{CP}, \mathrm{TC}$, and MK were also relatively low when compared with the marine water standards of Thailand ${ }^{29}$ and other estuaries in the world ${ }^{5,30-35}$. All study areas were located in rivers close to the sea. Hence there was a great decrease in the metal levels due to seawater, which, apart from the dilution effect (seawater has a low metal content), causes precipitation of large amounts of metals into the sediments as a result of the increased $\mathrm{pH}$ and salinity of the water ${ }^{5,35}$. In wet season the rain and flood dilute the metals and raise them to the sea.

The mean concentrations of $\mathrm{Cd}$ and $\mathrm{Cu}$ in sediments were higher than those of the water because the dilution effect can cause precipitation of large amounts of metals into the sediments as a result of the increased $\mathrm{pH}$ and salinity of the water when the input 


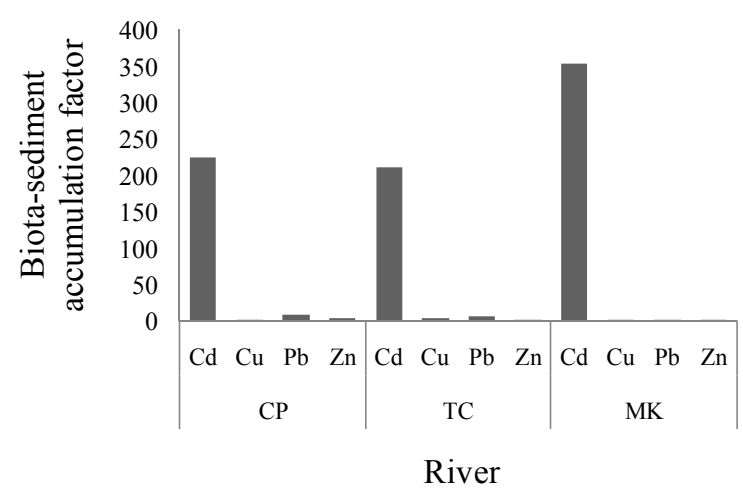

Fig. 2 BSAF (biota-sediment accumulation factor) of mangrove crab (S. mederi) in the Upper Gulf of Thailand. CP: Chao Phraya; TC: Tha Chin; MK: Mae Klong.

of water was decrease during the dry season ${ }^{5}$. The metal concentrations were not significantly different between dry and wet seasons in MK due to the effect of a dam that controls the water level in the river; most metals were deposited in the sediment under the water. The water of MK runs through the areas known for their $\mathrm{Pb}$ mines since historical times. Mining activities have left a large quantity of tailings, from which metal-rich and eroded materials are washed into the rivers and deposited in the MK sediments ${ }^{36}$.

The levels of metals recorded in the tissues of biota collected in the field varied among organisms. The metal accumulation was influences by prey selection $^{35}$. In this study, BSAF were low for $\mathrm{Cu}, \mathrm{Pb}$, and $\mathrm{Zn}$, but were high for $\mathrm{Cd}$ in all rivers as found by Ahmed et $\mathrm{al}^{37}$. Jara-Marini et $\mathrm{al}^{38}$ concluded that metals were not positively transferred through entire food web. Only specific organisms, such as filter feeders as S. mederi, showed signs of greater accumulation of $\mathrm{Cd}$. $\mathrm{Cd}$ and $\mathrm{Ca}$ are uptake by an energy-requiring pump in the epithelial cell membrane and then accumulation in the carapace or other part that have high concentration of $\mathrm{Ca}^{11,39}$. This result was similar to the studies on amphipods (Orchestia gammarellus) by Rainbow et $\mathrm{al}^{40}$ and Rainbow and $\mathrm{Kwan}^{41}$, which found that decreases in salinity produced predictable increases in metal uptake rate. This result was different from the study in Palaemon elegans and Palaemonetes varians by Nugegoda and Rainbow ${ }^{42,43}$ that decreases in salinity could decrease concentration of metals. This is similar to the study by Xiaobo et al ${ }^{12}$ in molluscs (Onchidium struma) that $\mathrm{Cu}$ is a cofactor for regulating the activity of $\mathrm{Cu}$ dependent enzymes ${ }^{12,44}$ and an essential component required for the synthesis of haemocyanin ${ }^{45}$. These results could be linked to the metal sequestration and detoxification by metallothionein proteins in the carapace. In general, metals undergo detoxification in the hepatopancreas and are subsequently excreted as granules from the epithelium of the hepatopancreas. As the main tissue for metal detoxification, the bioconcentration in the hepatopancreas could be the reflection of the whole body metal enrichment ${ }^{46}$.

Several studies have previously reported metal accumulations in crabs from different geographical areas (Table 3). Montes Nieto et $\mathrm{al}^{47}$ detected metal accumulation in the gill of Carcinus maenas in Spain and they found a correlation between metal accumulation and degree of industrialization. Firat et $\mathrm{al}^{48}$ found high concentrations of metals in shrimps (Penaeus semisulcatus) in Iskenderun Bay, Turkey, mainly caused by the wastewater drainage from the city nearby. This excessive metal concentration in river mounts of the upper gulf of Thailand may be caused by agricultural and industrial wastewater coming from upstream areas together with municipal wastewater from the cities nearby ${ }^{49}$.

It is important to detect metal concentrations in marine organisms because they allow determine whether these aquatic organisms may constitute a health hazard for consumers ${ }^{12}$. According to the current seafood standards regulated by the Food Standards Australia New Zealand ${ }^{50}$, the maximum allowable limits of $\mathrm{Cu}, \mathrm{Pb}$, and $\mathrm{Zn}$ are $100,1.5$, and $150 \mu \mathrm{g} / \mathrm{g}$ wet weight, respectively. However, no upper limits for $\mathrm{Cd}$ are specified by FSANZ ${ }^{50}$. The Hygienic Standard for Fresh and Frozen Marine Products of Animal Origin (GB 2733-2005) in China specifies the maximum levels of $\mathrm{Cd}$ in $0.5 \mu \mathrm{g} / \mathrm{g}$ wet weight and of $\mathrm{Pb}$ in $0.5 \mu \mathrm{g} / \mathrm{g}$ wet weight. In Thailand $(\mathrm{TH})$, Environmental Health Division ${ }^{28}$ only specifies the maximum levels of $\mathrm{Cd}(2 \mu \mathrm{g} / \mathrm{g}$ wet weight $)$ and $\mathrm{Pb}$ $(0.5 \mu \mathrm{g} / \mathrm{g} \text { wet weight })^{12}$. Hence based on the standard of FSANZ, GB 2733-2005 and TH, the accumulation of $\mathrm{Pb}$ the whole body and carapace of $S$. mederi in all rivers, and tissue in $\mathrm{CP}$ were higher than these standards, while tissue in TC and MK were higher than GB 2733-2005 and TH. Cd in the whole body was higher than these standards, while tissue and carapace were higher than FSANZ but lower than TH. All parts of $S$. mederi were lower than these standards.

$\mathrm{Cu}, \mathrm{Pb}$, and $\mathrm{Zn}$ in all rivers obtained BSAF ratios under 10 , which may be due to lesser bioavailability of these metals as compared to other metals. The BSAF of $\mathrm{Cd}$ and $\mathrm{Cu}$ were higher than in common barnacle (Balanus balanoides), while $\mathrm{Zn}$ was lower than the study made by Morillo et $\mathrm{al}^{5}$. If compared between the river sites, the BSAF of Cd was highest 
Table 3 Selected references of metal concentrations ( $\mu \mathrm{g} / \mathrm{g}$ dry weight) in crab species from different geographical areas (mean values and ranges).

\begin{tabular}{|c|c|c|c|c|c|c|}
\hline Site & Species & $\mathrm{Cd}$ & $\mathrm{Cu}$ & $\mathrm{Pd}$ & $\mathrm{Zn}$ & Reference \\
\hline $\begin{array}{l}\text { Chao Phraya River mount, } \\
\text { Thailand }\end{array}$ & $\begin{array}{l}\text { Sesarma mederi } \\
\text { Tissue (range) } \\
\text { Carapace (range) }\end{array}$ & $\begin{array}{l}1.19-1.55 \\
1.98-2.9\end{array}$ & $\begin{array}{l}64.78-113.97 \\
17.71-37.0\end{array}$ & $\begin{array}{l}0.47-13.43 \\
0.3-8.7\end{array}$ & $\begin{array}{l}169.11-259.5 \\
14.34-28.8\end{array}$ & This study \\
\hline $\begin{array}{l}\text { Tha Chin River mount, } \\
\text { Thailand }\end{array}$ & $\begin{array}{l}\text { S. mederi } \\
\text { Tissue (range) } \\
\text { Carapace (range) }\end{array}$ & $\begin{array}{l}1.26-1.7 \\
2.08-5.03\end{array}$ & $\begin{array}{l}83.91-123.53 \\
12.57-39.2\end{array}$ & $\begin{array}{l}0.24-1.26 \\
2.1-21.07\end{array}$ & $\begin{array}{l}162.82-223.76 \\
14.36-33.41\end{array}$ & This study \\
\hline $\begin{array}{l}\text { Mae Klong River mount, } \\
\text { Thailand }\end{array}$ & $\begin{array}{l}\text { S. mederi } \\
\text { Tissue (range) } \\
\text { Carapace (range) }\end{array}$ & $\begin{array}{l}1.22-3.11 \\
0.61-2.14\end{array}$ & $\begin{array}{l}89.63-105.12 \\
11.17-42.12\end{array}$ & $\begin{array}{l}0.15-0.84 \\
0.26-8.23\end{array}$ & $\begin{array}{l}177.2-231.39 \\
14.86-24.18\end{array}$ & This study \\
\hline $\begin{array}{l}\text { Huelva Estuary, SW Spain } \\
\text { Cádiz Bay }\end{array}$ & $\begin{array}{l}\text { Carcinus maenas } \\
\text { Gill } \\
\text { Gill }\end{array}$ & $\begin{array}{l}- \\
-\end{array}$ & $\begin{array}{l}66 \pm 10 \\
33.4 \pm 3.5\end{array}$ & $\begin{array}{l}17.2 \pm 6.1 \\
1.68 \pm 0.53\end{array}$ & $\begin{array}{l}118 \pm 22 \\
32.5 \pm 6.2\end{array}$ & Montes Nieto et $\mathrm{al}^{47}$ \\
\hline SE Gulf of California & $\begin{array}{l}\text { Callinectes arcuatus } \\
\text { Gill }\end{array}$ & $0.10 \pm 0.01$ & $60.3 \pm 5.4$ & $0.22 \pm 0.06$ & $39.4 \pm 1.4$ & Jara-Marini et al ${ }^{38}$ \\
\hline Ojo River, Nigeria & $\begin{array}{l}\text { Callinectes amnicola } \\
\text { Abdomen (male) } \\
\quad \text { (female) } \\
\text { Thorax (male) } \\
\text { (female) } \\
\text { Tissue (male) } \\
\text { (female) } \\
\text { Range }\end{array}$ & $\begin{array}{l}0.39 \\
0.35 \\
0.32 \\
0.35 \\
0.22 \\
0.17 \\
0.17-0.39\end{array}$ & $\begin{array}{l}- \\
- \\
- \\
- \\
- \\
- \\
-\end{array}$ & $\begin{array}{l}5.27 \\
3.28 \\
3.92 \\
2.87 \\
\text { ND } \\
0.83 \\
\text { ND-5.27 }\end{array}$ & $\begin{array}{l}9.33 \\
12.92 \\
8.31 \\
9.83 \\
15.75 \\
16.03 \\
8.31-16.03\end{array}$ & Olusegun et al ${ }^{18}$ \\
\hline Iskenderun Bay, Turkey & $\begin{array}{l}\text { Penaeus semisulcatus } \\
\text { Muscle } \\
\text { (range) } \\
\text { Gill } \\
\text { (range) } \\
\text { Hepatopancreas } \\
\text { (range) }\end{array}$ & $\begin{array}{l}25.4 \pm 7.8 \\
(16-37) \\
75.5 \pm 8.8 \\
(61.2-88.2) \\
111 \pm 23 \\
(90.3-149.6)\end{array}$ & $\begin{array}{l}78 \pm 12 \\
(60.8-96.2) \\
827 \pm 93 \\
(677.4-908.3) \\
935 \pm 50 \\
(870.7-1000.1)\end{array}$ & $\begin{array}{l}- \\
- \\
-\end{array}$ & $\begin{array}{l}32.5 \pm 7.0 \\
(25.1-45.7) \\
698 \pm 118 \\
(553.3-840.0) \\
805 \pm 103 \\
(846.3-950.0)\end{array}$ & Firat et al ${ }^{48}$ \\
\hline $\begin{array}{l}\text { Pearl River Estuary, } \\
\text { S China }\end{array}$ & $\begin{array}{l}\text { Portunus pelagicus } \\
\text { (range) }\end{array}$ & $\begin{array}{l}0.80 \pm 0.51 \\
(0.2-1.61)\end{array}$ & $\begin{array}{l}26 \pm 24 \\
(16.3-41.8)\end{array}$ & $\begin{array}{l}10.18 \pm 0.06 \\
(0.04-0.23)\end{array}$ & $\begin{array}{l}16.3 \pm 2.9 \\
(12.2-19.9)\end{array}$ & Ip et $\mathrm{al}^{51}$ \\
\hline Eerste River, S Africa & $\begin{array}{c}\text { Potamonautes perlatus } \\
\text { Whole (up stream) } \\
\text { (down stream) }\end{array}$ & $\begin{array}{l}3.4 \pm 2.8 \\
5.0 \pm 6.3\end{array}$ & - & $\begin{array}{l}16 \pm 19 \\
20 \pm 32\end{array}$ & - & Reinecke et al ${ }^{52}$ \\
\hline
\end{tabular}

at MK followed by $\mathrm{CP}$, and TC. We conclude that accumulation of $\mathrm{Cd}$ in $\mathrm{S}$. mederi, when compared to other organisms, is a good tool for monitoring metals even if the water has low concentration of these metals.

\section{CONCLUSIONS}

This study provides information related to accumulation of $\mathrm{Cd}, \mathrm{Cu}, \mathrm{Pb}$, and $\mathrm{Zn}$ in waters, sediments, and $S$. mederi in $\mathrm{CP}, \mathrm{TC}$, and $\mathrm{MK}$ of the upper gulf of Thailand. The results show that mangrove crabs accumulated metals in this ranking order: $\mathrm{Cd}>\mathrm{Cu}$ $>\mathrm{Pb}>\mathrm{Zn}$. The variation in metal concentration in waters and sediments depends on the activities of the human communities in the upper stream such as mining, industries and urbanization. Accumulation of $\mathrm{Cd}$ in $S$. mederi is a good tool for monitoring metals when compared to other organisms. Based on the results obtained, it was noted that the $\mathrm{Cd}, \mathrm{Cu}, \mathrm{Pb}$, and $\mathrm{Zn}$ are within the ranges found by other authors, but exceeded the maximum ranges of FSANZ and GB 2733-2005. As study species in the upper Gulf of Thailand are highly consumed as traditional food and it becomes famous as international Thai food, the relatively high accumulation of these metals detected may be a potential health hazard for its human consumers.

Acknowledgements: This study was supported by the faculty of Science, Mahidol University, Thailand. We are grateful to Norberto Asensio and John Laurence from Faculty of Environment and Resource Studies, Mahidol University for assistance with the proof reading of the manuscript.

\section{REFERENCES}

1. Marsden ID, Rainbow PS (2004) Does the accumulation of trace metals in crustaceans affect their ecology - the amphipod example? J Exp Mar Biol Ecol 300, 373-408.

2. Lee YH, Stuebing RB (1990) Heavy metal contamination in the river toad, Bufo juxtasper (Inger), near 
a copper mine in east Malaysia. Bull Environ Contam Toxicol 45, 272-9.

3. Gumgum B, Unlu E, Tez Z, Gulsun Z (1994) Heavy metal pollution in water, sediment, and fish from the Tigris River in Turkey. Chemosphere 290, 111-6.

4. Marcovecchio J (2004) The use of Micropogonias furnieri and Mugil liza as bioindicators of heavy metals pollution in La Plata River Estuary, Argentina. Sci Total Environ 323, 219-26.

5. Morillo J, Usero J, Gracia I (2005) Biomonitoring of trace metals in a mine-polluted estuarine system (Spain). Chemosphere 58, 1421-30.

6. Guerra-García JM, Ruiz-Tabares A, Baeza-Rojano E, Cabezas MP, Díaz-Pavón JJ, Pacios I, Maestre M, González AR, Espinosa F, García-Gómez JC (2010) Trace metals in caprella (Crustacea: Amphipoda): A new tool for monitoring pollution in coastal areas? Ecol Indicat 10, 734-43.

7. Karr JR (1981) Assessment of biotic integrity using fish communities. Fisheries 6, 21-7.

8. Cooper RJ, Langlois D, Olley J (1983) Heavy metals in Tasmanian shellfish 1-monitoring heavy metal contamination in the Derwent Estuary: Use of oysters and mussels. J Appl Toxicol 2, 99-109.

9. Leonzio C, Bacci E, Focardi S, Renzoni A (1981) Heavy metal in organisms from the northern Tyrrhenian Sea. Sci Total Environ 20, 131-46.

10. Yap CK, Ismael A, Tan SG (2004) Heavy metal (Cd, $\mathrm{Cu}, \mathrm{Pb}$, and $\mathrm{Zn}$ ) concentrations in the green-lipped mussel Perna viridis (Linnaeus) collected from some wild and aquacultural sites in the west coast of Peninsular Malaysia. Food Chem 84, 569-75.

11. Rainbow PS (1997) Ecophysiology of trace metal uptake in crustaceans. Estuar Coast Shelf Sci 44, 169-75.

12. Xiaobo L, Linzhi J, Yunlong Z, Qun W, Yongxu C (2009) Seasonal bioconcentration of heavy metals in Onchidium struma (Gastropoda: Pulmonata) from Chongming Island, the Yangtze Estuary. $J$ Environ Sci 21, 255-62.

13. Bayen S (2012) Occurrence, bioavailability and toxic affects of trace metals and organic contaminants in mangrove ecosystems: A review. Environ Int 48, 84-101.

14. Rainbow PS (2002) Trace metal concentrations in aquatic invertebrates: Why and so what? Environ Pollut 120, 497-507.

15. Calabrese EJ, Canada A, Sacco C (1985) Trace element and public health. Annu Rev Publ Health 6, 131-46.

16. Steward FM, Thompson DR, Furness RW, Harrison N (1994) Seasonal variation in heavy metal levels in tissues of common guillemots, Uria aalge from northwest Scotland. Arch Environ Contam Toxicol 27, 168-75.

17. Hungspreugs M, Yuangthong C (1984) The present levels of heavy metals in some molluscs of the Upper Gulf of Thailand. Water Air Soil Pollut 22, 395-402.

18. Olusegun AO, Olukemi TO, Olukemi MB (2009) Heavy metal distribution in crab (Callinectes amnicola) living on the shores of Ojo Rivers, Lagos, Nigeria. Environmentalist 29, 33-6.

19. Menasveta P, Cheevaparanapiwat V (1981) Heavy Metals, Organochlorine pesticides and PCBs in green mussels, mullets and sediments of river mouths in Thailand. Mar Pollut Bull 12, 19-25.

20. Polprasert C (1982) Heavy metal pollution in the Chao Phraya River Estuary, Thailand. Water Res 16, 775-84.

21. Hungspreugs $M$, Silpipat S, Tonapong C, Lee RF, Windom HL, Tenore KR (1984) Heavy metals and polycyclic hydrocarbon compounds in benthic organisms of the Upper Gulf of Thailand. Mar Pollut Bull 15, 231-18.

22. Suvapepun S (1991) Long term ecological changes in the Gulf of Thailand. Mar Pollut Bull 23, 213-7.

23. Hungspreugs M, Utoomprurkporn W, Dharmvanij S, Sompongchaiyakul P (1989) The present status of the aquatic environment of Thailand. Mar Pollut Bull 20, 327-32.

24. Schwartz MO, Rajan SS, Askury AK, Putthapiban P, Djaswadi S (1995) The Southern Asian Tin Belt. Earth Sci Rev 38, 95-293.

25. Thousombat $P$ (2005) The development of mangrove crab (Sesarma mederi) eggs to young crab. 31st Congress on Science and Technology of Thailand at Suranaree Univ of Technology, Thailand.

26. Vongvisessomjai S, Arbhabhirama A, Fuh Y (1978) A mathematical model of oil Spill movement in the Upper Gulf of Thailand. AIT Research Report No. 73, Thailand.

27. APHA (2005) Standard Methods for the Examination of Water and Wastewater, 20th edn, American Public Health Association, Washington, DC, USA.

28. Environmental Health Division (1984) Survey of the water quality in the estuary. Proceedings of the $3 \mathrm{rd}$ Seminar on the Quality of Living Resources in Thai Water. National Research Council of Thailand, Bangkok, Thailand, pp 62-78.

29. PCD (Pollution Control Department) (2006) Marine water quality standard. Pollution Control Department, Ministry of Natural Resource and Environment, Bangkok, Thailand.

30. Hungspreug M (1982) Baseline levels of cadmium, chromium, copper, lead, and zinc in seawater from the Gulf of Thailand. Sci Asia 8, 193-204.

31. Nolting RF, Helder W, de Baar HJW, Gerringa LJA (1999) Contrasting behavior of trace metals in the Scheldt Estuary in 1978 compared to recent years. J Sea Res 42, 275-90.

32. Power M, Attrill MJ, Thomas RM (1999) Heavy metal concentration trends in the Thames Estuary. Water Res 33, 1672-80.

33. Monbet P (2004) Dissolved and particulate fluxes of copper through the Morlaix River Estuary (Brittany, France): Mass balance in a small estuary with strong agricultural catchment. Mar Pollut Bull 48, 78-86.

34. Lewis M, Pryor R, Wilking L (2011) Fate and effects 
of anthropogenic chemicals in mangrove ecosystems: A review. Environ Pollut 159, 2328-46.

35. Bayen S (2012) Occurrence, bioavailability and toxic effects of trace metals and organic contaminants in mangrove ecosystems: A review. Environ Int 48, 84-101.

36. van Geen A, Adkins JF, Boyle EA, Nelson CH, Palanques A (1997) A 120-yr record of widespread contamination from mining of the Iberian pyrite belt. Geology 25, 291-4.

37. Ahmed K, Mehedi Y, Haque R, Mondol P (2011) Heavy metal concentrations in some macrobenthic fauna of the Sundarbans mangrove forest, south west coast of Bangladesh. Environ Monit Assess 177, 505-14.

38. Jara-Marini ME, Soto-Jiménez MF, Páez-Osuna F (2009) Trophic relationships and transference of cadmium, copper, lead and zinc in a subtropical coastal lagoon food web from SE Gulf of California. Chemosphere 77, 1366-73.

39. Rainbow PS (1995) Physiology, physicochemistry and metal uptake-a crustacean perspective. Mar Pollut Bull 31, 55-9.

40. Rainbow PS, Malik I, O’Brien P (1993) Physicochemical and physiological effects on the uptake of dissolved zinc and cadmium by the amphipod crustacean Orchestia gammarellus. Aquat Toxicol 25, 15-30.

41. Rainbow PS, Kwan MKH (1995) Physiological responses and the uptake of cadmium and zinc by the amphipod crustacean Orchestia gammarellus. Mar Ecol Progr 127, 87-102.

42. Nugegoda D, Rainbow PS (1989) Effects of salinity changes on zinc uptake and regulation by the decapods crustaceans Palaemon elegans and Palaemonetes varians. Mar Ecol Progr 51, 57-75.

43. Nugegoda D, Rainbow PS (1989) Salinity, osmolality and zinc uptake in Palaemon elegans (Crustacea: Decapoda). Mar Ecol Progr 55, 149-57.

44. Lehtonen KK, Leiniö S (2003) Effects of exposure to copper and malathion on metallothionein levels and acetylcholinesterase activity of the mussel Mytilus edulis and the clam Macoma balthica from the northern Baltic Sea. Bull Environ Contam Toxicol 71, 489-96.

45. Méndez L, Racotta IS, Acosta B, Rodríguez-Jaramillo C (2001) Mineral level in tissue during ovarian development of white shrimp Penaeus vannamei (Decapoda: Penaeidae). Mar Biol 138, 687-92.

46. MacFarlane GR, Burchett MD (2000) Cellular distribution of copper, lead and zinc in the grey mangrove Avicennia marina (Forsk.) Vierh. Aquat Bot 68, 45-59.

47. Montes Nieto R, García-Barrera T, Gómez-Ariza JL, López-Barea J (2010) Environmental monitoring of Domingo Rubio stream (Huelva Estuary, SW Spain) by combining conventional biomarkers and proteomic analysis in Carcinus maenas. Environ Pollut 158, 401-8.

48. Firat Ö, Gök G, Çoğun HY, Yüzereroğlu TA, Kargin F
(2008) Concentrations of $\mathrm{Cr}, \mathrm{Cd}, \mathrm{Cu}, \mathrm{Zn}$ and $\mathrm{Fe}$ in crab Charybdis longicollis and shrimp Penaeus semisulcatus from the Iskenderun Bay, Turkey. Environ Monit Assess 147, 117-23.

49. Srisuksawad K, Porntepkasemsan B, Nouchpramool S, Yamkate P, Carpenter R, Peterson ML, Hamilton T (1997) Radionuclide activities, geochemistry, and accumulation rates of sediments in the Gulf of Thailand. Continent Shelf Res 17, 925-65.

50. FSANZ (Food Standards Australia New Zealand) (2002) Contaminants and natural toxicants. Standard 1.4.1 of the Australia New Zealand Food Standards Code V.2, NZ.

51. Ip CCM, Li XD, Zhang G, Wong CSC, Zhang WL (2005) Heavy metal and $\mathrm{Pb}$ isotopic compositions of aquatic organisms in the Pearl River estuary, South China. Environ Pollut 138, 494-504.

52. Reinecke AJ, Snyman RG, Nel JAJ (2003) Uptake and distribution of lead $(\mathrm{Pb})$ and cadmium $(\mathrm{Cd})$ in the freshwater crab, Potamonautes perlatus (Crustacea) in The Eerste River, South Africa. Water Air Soil Pollut 145, 395-408. 